\title{
Digitális tankönyvek - szülői percepciók
}

\author{
Hátsek Kinga Mária \\ Petőfi Sándor Általános Iskola Csíkszereda
}

\section{Bevezető}

A digitális világ akarva-akaratlanul behálózza mindennapjainkat, a digitális bennszülöttek (Prensky, 2011) egész eddigi, néhány éves életüket úgy élték le, hogy számítógépek, táblagépek, videokamerák és mobiltelefonok vették körül őket. A digitális bennszülött kifejezés gyermekeink, tanulóink megnevezésére szolgál, akik beleszületnek és uralják azt a világot, amit szüleik sok esetben idegenkedve, félelemmel és tiltással kezelnek. Bár az információs technológia felhasználása az élet minden területén elterjedt, a készségek elsajátítása többnyire az oktatási intézményeken kívül történik (Sárosi-Blága, 2016), ez az ellentmondásos állapot tanulóknak, szülőknek és pedagógusoknak egyaránt kihívást jelent.

A felgyorsult és sok esetben kontrolálhatatlan digitalizálódási folyamat tette szükségszerüvé és termelte ki Romániában a digitális tankönyvek bevezetésének ötletét, majd a konkrét megvalósítási formát illető sok bizonytalanságot követően a 2014/2015-ös tanév közepén az iskolákban is megjelentek ezek. Az említett, leginkább a média által keltett bizonytalanságnak köszönhetően mai napig több szülő sem tudja, hogy a gyermeke taneszközeinek tartozéka a digitális tankönyv, pedig ezt vagy ezeket naponta használja a tanuló.

Tanulmányomban egy szük körben végzett kutatás eredményeit mutatom be a szülők digitális tankönyvekhez való viszonyulását illetően. A téma időszerüségét jelzik a Nemzetközi Gyermekmentő Szolgálat által támogatott, “A média hatása a gyermekekre és fiatalokra" székelyföldi kutatási program eddigi eredményei. A digitális tankönyvek tematizálása újdonságnak számít nemcsak térségi, hanem országszinten, és jelen kutatással egy egészen fiatal korosztály - másodikos és harmadikos tanulók - médiahasználati szokásaiba, valamint szüleik viszonyulásának alakulásába nyertem betekintést. A fent említett programsorozatnak köszönhetően számos esettanulmány és mélyinterjúkra alapozó kutatás zajlott (Bodó, 2012) a pedagógusi véleményekről, a szülő-gyermek kapcsolattal, illetve a családi szabályozás kérdésével kérdőíves (Gergely, 2013) és interjús vizsgálatok (Gocz, 2016) foglalkoztak. Ezekből arról értesültem, hogy a gyermekek internethasználatát illetően a felkészítést a szülők nagymértékben az iskolára hárítják, igényüket fejezték ki az osztálytermek megfelelő technikai 
eszközökkel való felszereltségére, valamint a pedagógusok kulcsfontosságát hangsúlyozták ebben a folyamatban. Ezek tükrében arra következtethetünk, hogy a digitális tankönyvek megjelenése és célszerü használata sok problémát orvosol, több, a szülők által felhozott igényre megoldást szolgáltathat.

\section{Mi a digitális tankönyv?}

A jelenleg Romániában érvényben levő digitális tankönyvek a könyv formátumhoz csatolt CD által váltak IKT-eszközökké, túlnyomó részük az I-IV. osztályos tanulók számára készültek. Az előzőekben említett szülői értetlenkedést az is kiválthatta, hogy a média táblagépes digitális tankönyvekről szórt széles körben információt még a konkrétumok megjelenése elött. A közvélemény a sajtónak köszönhetően sok ideig azzal is foglalkozott, hogy minden tanulónak lesz-e táblagépe, és azt vissza kell-e majd szolgáltatni az iskolának, államnak stb. Ebből is adódhatott tehát, hogy sok szülö még mindig nem tud a gyermeke tanszertárában fellelhetö digitális tankönyvröl. A digitális taneszköz az oktatás folyamatában felhasználható, az oktatás céljainak elérését segítő digitális úton előállított és digitális formában elérhető eszköz (Ballér és mások, 2003)

Eszerint a digitális eszközök csak akkor töltik be innovatív funkciójukat, ha nemcsak formailag különböznek társaiktól, hanem olyan digitális megoldásokkal élnek, amelyekkel könyvalapú társaik nem képesek a tanulás hatékonysága és élvezhetősége érdekében.

A pedagógusok és a közvélemény informálása, a kételyek eloszlatása végett Constantin Cucoș "antropológiai fordulatnak" nevezte a digitális tankönyvek bevezetését, és nagy változásokat prognosztizált, azt azonban ő is megerősítette, hogy ezek használatát illetően anyagi jellegü problémák lesznek, a digitális taneszközök hozzáférése nem lesz azonos mértékben adott minden tanuló számára. A Tribuna învățământului címủ szakmai kiadványban azt hangsúlyozta, hogy a digitális tankönyvek jó lehetőséget jelentenek bizonyos korosztály számára a tanulás iránti motiváció megteremtésére, ezek nem a nyomtatott eszközöket helyettesítik vagy azok másolatai, hanem az aktivitást, az interakciót és a kreativitást célozzák (Cucoş, 2013). A tanulás digitalizálása a curriculum megvalósításának lehetőségeit, megoldásait és feltételeit nyújtja. A digitális tankönyvek kiegészítik, de nem helyettesítik a klasszikus tankönyveket, ez utóbbiak további használata fontos pszichológiai, didaktikai és antropológiai szempontból egyaránt - véli Cucoș. Ugyanakkor a klasszikus módon elsajátított alapkompetenciák (olvasás, írás, jelfelismerés) szükségesek a digitális tankönyvek használatához, amelyek jövőképét illetően a jelenkori román pe- 
dagógiaoktatás szaktekintélye úgy prognosztizált, hogy a két taneszközforma a jövőben 20-30 évig fog együtt létezni.

Napjaink egyik nagy kérdése, hogy mennyi idős korban engedjük a gyereknek a digitális eszközök használatát. Cucoș szerint "már az óvodás könynyüszerrel bánik a táblagéppel”, az írás-olvasás elsajátításban azonban inkább a klasszikus eszközöket ajánlja, hiszen ezek magasabb fokú elmélyülést igényelnek, hosszabb távú rögzítést biztosítanak. Az akadémikus a digitális tankönyvek mellett szóló érvelésében azt hangsúlyozza, hogy ezek CD-n vagy internetes kapcsolattal bárhol hozzáférhetőek, a nyomtatott formához hasonló kép- és feladatrendszer vonzó, színes, gyermekbarát, az életkori sajátosságoknak megfelelően készültek. Véleménye szerint ezek az eszközök hasznosak, segítséget jelentenek a tanítás-tanulásban, a videók és hanganyagok felkeltik a tanulók érdeklődését.

\section{Hiba csúszott a rendszerbe}

Gyakorló pedagógusként megéltem az elemi osztályosok számára elkészített digitális tankönyvek megjelenését, ami gyakorlatilag mindannyiunk számára meglepetés volt: tanév közben érkeztek, sok iskolában nem voltak megfelelő eszközök ezek használatára, a pedagógusok kiosztották a tankönyveket a hozzájuk csatolt CD-kel, és a szülők így találkoztak az új taneszközzel. Teljes mértékben az IKT-eszközök megléte vagy hiánya határozza meg, hogy az iskolában, otthon vagy mindkét helyen használják-e a gyerekek a digitalizált változatot, egyáltalán élnek-e azzal a lehetőséggel, amit számukra az ezt megálmodó és kivitelező személyek megteremtettek. Személyes véleményem, hogy pontosan akkor nem beszélt a média a digitális tankönyvekről, amikor ezek a célcsoport kezébe kerültek, így sok esetben "a fürdővízzel a gyermeket is kiöntöttük" effektus érvényesült, információ-, felvilágosítás- és eszközhiány okán az oktatási folyamat fontos szereplői, a szülők nem értesültek kellőképpen a modern taneszköz bevezetéséröl.

A digitális tankönyvek bevezetésének másik nagy problémája volt a folytonosság és következetesség hiánya, több tantárgyból csak egy-két évfolyamra terveztek, másokból egyáltalán nem. Bizonyos évfolyamokon (I. és II. osztály) a tanulók anyanyelvi nevelésből, román és angol nyelvből, matematikából és környezetismeretből kaptak digitális tankönyveket. Pedagógusként saját osztályomban tanórákon a gyerekek számára esemény volt, ha ezeket használhatták, élvezettel és könnyüszerrel bántak az oktatóprogramokkal, vonzóbbá és érdekesebbé tette a napi tevékenységeket. A digitális bennszülötti státusszal járó 
attitüd egyértelmüen igazolódott, egyre többen használták otthon is rögzítés végett a digitális formában elérhető feladatokat.

\section{A szülők viszonyulása}

Mivel az oktatás több összetevős folyamat, sikerét a gyermek-szülő-pedagógus együttmüködése feltételezi, kíváncsi voltam a szülök viszonyulására a digitális tankönyvek használatát illetően. Az új taneszköz bevezetése másfajta szülői együttműködést feltételezett, különböző anyagi hozzáállás és meggyőződés tükröződött a visszajelzésekből, empirikus tapasztalataim is ezt bizonyították.

Empirikus tapasztalataimat tudományos módon végzett vizsgálattal akartam gazdagítani, pedagógusként fontosnak tartottam a szülői hozzáállásra fényt deríteni. Kutatásomat a csíkszeredai Petőfi Sándor Általános Iskola második és harmadik osztályos tanulói körében végeztem önkitöltős, családokhoz hazaküldött kérdőívekkel, 160 személyes mintán. Azért választottam ezt a két évfolyamot, mert mindkét esetben legalább 1 évig lehetőségük volt a gyerekeknek használni az újszerü oktatási eszközöket, így a szülöknek is lehetőségük adódott ezek megismerésére. Miután a gyerekek körében egyértelmüen sikeres fogadtatásuk volt a digitális tankönyveknek, feltételeztem, hogy a szülök körében is hasonlóan népszerüek. Ennek érdekében a következő kérdéseket tartalmazó kérdőívvel fordultam a szülőkhöz:

Mit gondol a hagyományos tankönyvekröl?

Milyen elvárásokat fogalmazott meg a digitális tankönyvekkel kapcsolatosan? Mennyit módosított időben az otthoni tanulás terén a digitális tankönyvek használata?

Mely tantárgyból tartja indokoltnak a digitális tankönyvek használatát?

Milyen mértékben igényli gyermeke a szülöi segítséget a digitális tankönyvek használatában az otthoni tanulásban, házi feladatok elkészítésében?

Mennyire könnyíti meg a digitális tankönyv a gyermek otthoni tanulását?

Mikor tudja használni a gyermek otthon a digitális tankönyvet?

Milyen típusfeladatokat tart fontosnak otthon is gyakoroltatni a CD-röl?

Kérjük, fogalmazza meg a digitális tankönyvekkel kapcsolatos észrevételeit, javaslatait!

Arra, hogy mit gondolnak a szülök a hagyományos tankönyvekről, a többség vélekedése alapján egyértelmü választ kaptam: a régi és új taneszközök egyidejü használatát szeretnék a legtöbben, 73,8\%-ban (1. táblázat). 
Digitális tankönyvek - szülöi percepciók

\begin{tabular}{|l|c|}
\hline \multicolumn{1}{|c|}{ válaszlehetőségek } & válaszok százalékos eloszlása \\
\hline 1. Idejét múlta & 2,3 \\
\hline 2. Szerettem, de jól jött az újítás & 20 \\
\hline 3. Egyáltalán nem időszerúek & 3,8 \\
\hline 4. Párhuzamosan múködhetne régi és új & $\mathbf{7 3 , 8}$ \\
\hline
\end{tabular}

1. táblázat

Mit gondol a hagyományos tankönyvekröl?

A digitális tankönyvekkel megfogalmazott elvárásokkal kapcsolatosan legtöbben arra voltak kíváncsiak, hogy miben hoz újat (48,9\%), ennek fele úgy gondolta, hogy megér egy próbát (23\%), szinte azonos arányban vannak azok a szülők, akik örültek $(12,6 \%)$ illetve akik egyáltalán nem örültek neki $(15,6 \%)$.

A hagyományos tankönyveket illetően a másodikosok körében 69,6\%-ban, míg a harmadikos szülök közül 66,7\%-ban vélték úgy, hogy párhuzamosan müködhetne a régi és új, csupán 1,4\%-ban a másodikosok, míg 2,9\%-ban a harmadikosok szülei szerint idejét múlta a hagyományos tankönyvek használata. Egyenlő arányban, mindkét évfolyamon 18,8\%-os megoszlásban választották a szerettem, de jól jött az újítás megoldást. Már az első kérdésnél az derült ki, hogy a klasszikus tankönyveken szocializálódott szülöi társadalom nyitott az újításra, de biztonságérzetük a kettősségre készteti őket, így a digitális taneszköz mellé mindenképpen a papíralapú tankönyvet is szeretnék.

A média által a megjelenést jóval hamarabb megelőző hírverésnek köszönhetően a szülők képzetvilágában sokrétüen jelentkeztek a digitális tankönyvek, ennek megfelelően elvárásokat is fogalmaztak meg. A másodikos szülőknek pontosan fele $(50,7 \%$-a), a harmadikosoknál ennél kevesebben (43,5\%) voltak kíváncsiak, miben hoz újat, mindkét évfolyam esetében közel annyian örültek a digitális tankönyveknek, mint ahányan az egyáltalán nem örültem neki választ jelölték meg. A megér egy próbát válasz mellett voksolók (23,2\% illetve 21,7\%) akárcsak a kíváncsiak csapata felismerte, hogy gyermekeik generációja már a digitális eszközök világában érzi igazán jól magát, mégis a saját gyermekkoruk áldott vagy átkos papírtankönyveit részesítik előnyben.

A visszajelzések alapján a gyerekek nagy többsége $(66,4 \%)$ ugyanannyi időt tölt az otthoni tanulással, mint a digitális tankönyvek megjelenését megelőzően, ennek egyharmada (20,7\%) több időt tanul így, mint a hagyományos 
tankönyvekkel, csupán $12,1 \%$ válaszolta azt, hogy a digitális tankönyveknek köszönhetően a gyermek kevesebb időt tölt otthon a tanulással.

A tantárgyakat illetően a román- és az angol nyelv tanulásával kapcsolatban választották a legtöbben a nagyon fontos és fontos álláspontot: 69,4\%-ban angol nyelvböl, 60,9\%-ban román nyelvböl (2. táblázat).

\begin{tabular}{|c|c|c|}
\hline válaszlehetőségek & angol nyelv & román nyelv \\
\hline fölösleges & 5,2 & 7,5 \\
\hline kevésbé fontos & 4,5 & 6 \\
\hline is-is & 20,9 & 25,6 \\
\hline fontos & 28,4 & 21,1 \\
\hline nagyon fontos & $\mathbf{4 1}$ & $\mathbf{3 9 , 8}$ \\
\hline
\end{tabular}

2. táblázat

Mely tantárgyból tartja indokoltnak a digitális tankönyvek használatát?

A másodikos gyerekek szüleinek 60,9\%- a illetve 69,5\%-a tartja fontos és nagyon fontos megoldásnak a digitális tankönyvek használatát, míg a harmadikosok körében 55\%-a illetve 63,8-a. A CD-ken található audíciós gyakorlatok, dalok, versek nagymértékben segítik a tanulók nyelvi képességeinek fejlődését, ezt a szülök is felismerték. Az angol nyelv tekintetében mutatkozó preferencia annak is tulajdonítható, hogy a szülök egy része nem tud segíteni a gyermeknek, így a digitális megoldás nagy segítség.

Az anyanyelv, matematika és természettudományok terén nagyon kis százalékban tartják fontosnak és nagyon fontosnak mindkét évfolyamon a digitális tankönyvek használatát (10-20\% között), többen nem is jelöltek egy opciót sem ezeknél a tantárgyaknál. Ebben az esetben újra a szülőknek a saját gyermekkorukhoz kötődő emlékeik vezérelte viszonyulásuk mutatkozik meg, miszerint az anyanyelvi, matematika- és természettudományos tanulás-gyakorlás müködik papír-ceruza eszközökkel is. Ide kapcsolódik az a vélekedésük is, hogy a digitális tankönyvek csak valamennyire könnyítették meg a gyerekek otthoni tanulását - 62,3\%-ban a másodikosok és 44,9\%-ban a harmadikosok esetében, míg az egyáltalán nem is jelentős arányban - 14,5\%-ban valamint 18,8\%-ban jelentkezett.

Főleg az elemi osztályos tanulók esetében jellemző a szülői segítség az otthoni tanulást illetően. Mivel eszközfüggő a digitális tankönyvek használata, a pedagógusok nem tudják kötelezni ezek otthoni használatát, illetve a házi feladatok kijelölésében is körültekintően kell eljárniuk. Saját tapasztalatom, 
hogy a "nem kötelező, de otthon is lehet gyakorolni" megoldások sok esetben szimpatikusak a gyerekek számára, így lehetőség szerint önállóan is dolgoznak a digitális tankönyvekböl. A megkérdezett szülők fele (48,9\%-a) felelte azt, hogy néha igényli a gyermek a szülői segítséget az ilyennemü tevékenységekben, ennek a mennyiségnek fele gyakran igényli $(25,4 \%)$, kevesebben mindig a szülővel dolgoznak a digitális platformon (18,3\%), míg 7,9\%-ban soha.

A KAM - Regionális és Antropológiai Kutatások Központja által több éve zajló, a szülök viszonyulása és attitüdjének kutatása témakörének köszönhetöen több tanulmányban olvashattam a hetedik osztályos gyerekek otthoni internethasználatával kapcsolatos szabályozásokról (Lázár, 2015, Berényi, 2013).

A kamaszodó gyerekek esetében arról számolnak be a tanulmányok, hogy már nehezen kontrollálhatók a virtuális térben végzett tevékenységek, kevésbé ellenőrizhetők, kevésbé befolyásolhatók, ezt a szülők különbözőképpen próbálják kezelni, különbözőképpen értelmezik, értékelik. A kamaszodó társával ellentétben a kisiskolás gyermek sokkal inkább szabálykövető és szófogadó, kutatásomban arra kaptam megerősítést, hogy a szülök többsége még időben igyekszik a korlátok felállítására (3. táblázat). Eszerint a napi digitális tankönyvhasználatban a gyerekek több, mint fele felügyelettel (56,6\%), negyede korlátozással (25,3\%) és csupán 18,1\%-a korlátlanul tevékenykedik. Egy másik, a kisiskolások esetében gyakran alkalmazott módszer a csak hétvégén engedélyezett számítógépezés és az akkor használt digitális oktatóprogramok, a válaszok alapján a szülök ezt is szeretik korlátozni (45,7\%), illetve felügyelni $(37,1 \%)$.

\begin{tabular}{|c|c|c|}
\hline válaszlehetőségek & minden nap \% & csak hétvégén \% \\
\hline korlátlanul & 18,1 & 17,1 \\
\hline felügyelettel & $\mathbf{5 6 , 6}$ & 37,1 \\
\hline korlátozással & 25,3 & $\mathbf{4 5 , 7}$ \\
\hline
\end{tabular}

\section{3. táblázat}

Mikor tudja használni a gyermek otthon a digitális tankönyvet?

Mivel a digitális leckék számos típusfeladattal (audíciós gyakorlatok, memóriajátékok, helyesírási gyakorlatok, szövegértési-, asszociációs- és “igaz-hamis" feladatok,) igyekeznek a gyerekek fejlesztéséhez hozzájárulni, arra kerestem a választ, hogy a szülő mit tart fontosnak gyakoroltatni ezek közül. Az 
audíciós gyakorlatok esetében 68,7\%-ban jelölték nagyon fontosnak és fontosnak a gyakorlást, a helyesírási szabályokat rögzítő feladatok esetében 70,7\%ban jelölték meg ezt a két szempontot.

A kérdőívben a szülők lehetőséget kaptak szabad válaszok által saját álláspontjuk megfogalmazására, ezzel a lehetőséggel sokan éltek, és a digitális tankönyvek hasznáról illetve hátrányáról vélekedtek (4-5. táblázat). Mint már az előbbiekben is kiderült, az idegennyelv tanulásában megmutatkozó lehetőséget többen is felismerték, az is nyilvánvalóvá vált, hogy a szülők szerint érdekes és egyszerübb tanulási lehetőség rejlik a digitális tankönyvekben. A hátrányokról is szép számban nyilatkoztak, a legtöbben attól tartanak, hogy az ilyenfajta didaktikai eszköz miatt a gyermek még több időt tölt a számítógép előtt, a papíralapú tankönyveken felnőtt szülői generáció másik félelme az, hogy a gyermek elfelejti a könyv formáját, számítógépfüggővé válik.

\begin{tabular}{l} 
A digitális tankönyvek haszna \\
hasznos az idegen nyelv tanulásában \\
érdekes tanulási lehetőség \\
egyszerübb így a tanulás \\
modern eszköz \\
praktikus \\
nincs előnye \\
\hline
\end{tabular}

válaszok száma

\begin{tabular}{|l|c|}
\hline A digitális tankönyvek hátránya & válaszok száma \\
\hline függőséget okoz & $\mathbf{6}$ \\
\hline több idő a számítógép előtt & 23 \\
\hline technikafüggő & $\mathbf{6}$ \\
\hline elfelejti a gyerek a könyv formáját & $\mathbf{7}$ \\
\hline időigényes & $\mathbf{2}$ \\
\hline
\end{tabular}

4-5. táblázat

A digitális tankönyvek elönye és hátránya 


\section{Következtetések}

A térségünkben e témában végzett kutatásokat folyamatában nézve megállapíthatjuk, hogy a gyermekek digitáliseszköz-használatát tekintve létezik egyfajta tudatosság, a stratégiák beépülnek a többi gyermekneveléssel kapcsolatos probléma- és feladathalmazba (Biró, 2013).

Az IKT-eszközök rohamszerü elterjedése, valamint a digitális taneszközök a szülöket is újabb helyzetbe hozták. Egyértelmüen tudatában vannak annak is, hogy gyermekeik csak a digitális kompetenciák birtokában fognak tudni érvényesülni a jövőben, viszont védeni szeretnék őket a virtuális világ veszélyeitől ameddig csak lehet. Ennek érdekében még a taneszközök terén is szívesebben látnák gyermeküket a klasszikus tankönyvekböl dolgozni, mint a számítógépet használva.

\section{Felhasznált irodalom}

Ballér Endre, Golnhofer Erzsébet, Falus Iván, Kotschy Beáta, M. Nádasi Mária, Nahalka István, Petriné Feyér Judit, Réthy Endréné, Szivák Judit, Vámos Ágnes (2003): Didaktika. https://www.tankonyvtar.hu/hu/tartalom/tamop425/2011_0001_519_42498_2/ch12s02.html

Berényi Hajnal (2013): Szülő-gyerek kapcsolatok és az internet. In. Biró A. Zoltán, Bodó Julianna (szerk.): Internethasználat vidéki térségben. A média hatása a gyermekekre és fiatalokra. Státus kiadó, Csíkszereda. 67-85.

Biró Z. Zoltán (2013): Vélekedés és gyakorlat. Kisgyerekes családok percepcióinak elemzése a gyerekek jövőbeli internethasználatával kapcsolatosan. In. Biró A. Zoltán, Bodó Julianna (szerk.): Internethasználat vidéki térségben. A média hatása a gyermekekre és fiatalokra. Státus kiadó, Csíkszereda. 88-99.

Bodó Julianna (2013): Internethasználat és oktatás. In. Biró A. Zoltán, Bodó Julianna (szerk.): Internethasználat vidéki térségben. A média hatása a gyermekekre és fiatalokra. Státus kiadó, Csíkszereda. 138-157.

Cucoş, C. (2013): Manualul digital-perspectivă pedagogică. www.tribunainvatamantului.ro/manualul-digital-constantin-cucos/

Cucoş, C. (2015): Învăţarea pe suport digital: dileme, probleme, perspective. http://www.constantincucos.ro/2015/04/invatarea-pe-suport-digital-dileme-probleme-perspective

Gocz Izabella (2016): Internethasználat szülöi szemmel. In. Biró A. Zoltán, Bodó Julianna (szerk.): Internet - Iskola - Anyanyelv. A média hatása a gyermekekre és fiatalokra. Státus kiadó, Csíkszereda. 165-186. 
Lázár Csilla (2015): Szülők kontra gyerekek - a telekommunikációs eszközök használatáról. In. Biró A. Zoltán, Gergely Orsolya (szerk.): Kihívások és megoldások. A média hatása a gyermekekre és fiatalokra. Státus kiadó, Csíkszereda. 178-186.

Prensky, M. (2001): Digital Natives, Digital Immigrants. On the Horizon 9. 5. sz. 1-6.

Sárosi-Blága Ágnes (2016): Tények és kihívások az információs-kommunikációs technológiák oktatási integrációjában. In. Biró A. Zoltán, Bodó Julianna (szerk.): Internet - Iskola - Anyanyelv. A média hatása a gyermekekre és fiatalokra. Státus kiadó, Csíkszereda. 9-60.

\section{Abstract \\ Digital textbooks - Parental perceptions}

Quickening and in many cases uncontrolled digitization brought in the necessity for and the availability of digital textbooks in schools that appeared also in Romania. Partly caused by the media, there is uncertainty among parents about the role of these textbooks as it is not clear for them that digital textbooks are regular, everyday learning tools. 